\title{
Cyber-Bullying Prevention Effort with Multicultural Education Approaches in School
}

\author{
Sylvi Marini, Setyabudi Indartono, Farida Hanum
}

\begin{abstract}
This study had purposed to describe the efforts prevent cyber-bullying in schools through a multicultural education approach. The main problems of implementation and models of cultivation multicultural education values among students are could to prevent cyber-bullying at school is happened. The method had used in this study is qualitative with the type of library research method. The results illustrated are the implementation of multicultural education in schools is supported through the school climate, school curriculum, school advice and infrastructure, the role of teachers, school programs and activities as well as students. The method chosen in value management is based on students' dynamics, relaxed and does not suppress students. When teaching in class the teacher also applies multicultural education by familiarizing the mutual respect for one another, creating a democratic classroom atmosphere, and instilling multicultural values routinely. With these policies, it is expected that education will make a significant contribution to the problem of cyber-bullying. Through education in schools the development of open attitudes towards diversity, tolerance, and understanding togetherness as needs will be able to be invested and developed as capital in the life of the nation and state so as cyber-bullying events can be prevented before they occur.
\end{abstract}

Keywords: Cyber-bullying, Implementation, Multicultural Education

\section{INTRODUCTION}

The development and progress in field of information and communication technology are given birth to social media with various applications such as WhatsApp, Instagram, Twitter and other applications. By using the application, for most people receiving messages is fun because it can not only communicate, search for information, but could send pictures too, and send videos. But not so at this time, many circulations of message were smelled of news Hoax, fraud under the guise of gifts, and the occurrence of hacking of personal identities from unknown numbers make users of this application become uneasy. Even so, it turns out there is also no less widespread in the internet world namely online bullying (cyber-bullying). According to Bauman et al. (2013) [1] the negative impacts of the internet include: internet addiction, cyber-bullying, cyber pornography, health risks, fraud and violence are distort adolescent development.

Cyber-bullying is a new form of conventional bullying has done with using information and communication technology. According to Belsey (Bauman, 2007) [2]: "Cyber-bullying involves the use of information and communication technologies such as e-mail,

Revised Manuscript Received on August 15, 2019.

* Correspondence Author

Sylvi Marini*, Master's Program in Social Studies Education, Yogyakarta State University, Yogyakarta, Indonesia E-mail: sylvimarini.2017@student.uny.ac.id

SetyabudiIndartono, UNYMaster's Program Lecturer, Yogyakarta State University, Yogyakarta, Indonesia E-mail: Setyabudi_indartono@uny.ac.id

Farida Hanum, UNYMaster's Program Lecturer, Yogyakarta State University, Yogyakarta, Indonesia E-mail: Farida_Hanum@uny.ac.id

(c) The Authors. Published by Blue Eyes Intelligence Engineering and Sciences Publication (BEIESP). This is an open access article under the CC BY-NC-ND license (http://creativecommons.org/licenses/by-nc-nd/4.0/) cell phone and pager text messages, instant messaging, defamatory personal Websites, and online defamatory personal polling Websites, to support deliberate, repeated, and hostile behavior by an individual or group is intended to harm others ". The cyber-bullying treatment can occur to a child or teen or a group of teenagers through the use of the internet (digital interactive or mobile devices). This happens due to teenagers are one of the internet users who have increased use ratios especially in social networks, instant messaging applications and chat rooms. The following data from APJII (2018) [3] of internet users today shows that the age range of $13-18$ years is 16.68 percent, while $19-34$ years old is the main contributor of the age of users with 49.52 percent. Teenagers in question are teenagers who are feeling a sense of solidarity and are looking for identity through the application. (Anderson et al. 2014[4]; Palladino et al., 2015[5]).

Based on the latest research conducted by Anderson (2018) [6] is only found 59\% of US teens personally have experienced at least one of the six types of cruel online behavior such as name calling and the spread of gossip is unpleasant in the lives of adolescents. Besides that, according to Ditch the Label survey data (2017) from 10,020 respondents aged 12 to 20 years it was revealed, the use of Instagram is the social media with the highest verbal violence in 2017 and Facebook being the second violent media.

The traditional behavior of bullying and cyber-bullying (bullying behavior in the school environment) has several similarities (Bauman et al., 2013[7]; Waasdorp, T., \& Bradshaw, C,. 2015 [8]). In fact, it has been found, that the negative impact of cyber-bullying is more severe when compared to traditional bullying. The reason is, just by doing a "click", attacks of words or slander can spread quickly. The sender could be uploaded the photos or images that make the victim uncomfortable. Sexting can also be in the form of cyber-bullying when the offender can send photos, pictures, messages is sexually memorable via telephone, computer, or other digital devices. In addition, the sender's anonymity could make it difficult to find the real culprit. The sender could to use a fake name when he attacks the victim. This makes it difficult to stop cyberbullying.

Cyber-bullying child victims are usually experience fear to meet with friends, go to school, and even to discuss the problem with parents. Long-term effects are quite serious, including depression, self-harm, withdrawing from friendship, to suicide. Other possible impacts include decreased self-confidence, failure at school, emotional and psychological damage, deep sadness and frustration. Victims can also experience sleep and eat disturbances, close themselves from relationships, and others. 
One of factor is occurrence of bullying and possibly happened cyber-bullying in the educational environment, especially schools, this is caused by differences in backgrounds owned by students. These differences can be physical or non-physical, all of which are included in multicultural differences. The difference that is owned by each person causes everyone to have different needs and competencies.

As an effort to prevent the negative impacts of the digital world, it should be done in the family, play environment, school environment, work environment and mass media. Based on the writer's observations the school environment has an important role in preventing anti-cyber bullying through the cultivation of multicultural education. Multicultural education is a renewal, process and form of education that aims to provide opportunities for all students (whether or not with special needs) regardless of gender, social class, ethnicity, race, religion, and culture in order to realize social justice, equal education and dedication in provide learning experiences so that students can achieve optimal development and achieve academic achievement in school. So that it is hoped that through multicultural education at school a teenager or group of young people can respect these differences and create a culture of tolerance in association and narrow the occurrence of cyber-bullying actions.

\section{II.CONCEPT OF CYBER-BULLYING}

Cyber-bullying is a new form of conventional bullying done using information and communication technology. According to Tokunaga mentioned that Cyber-bullying is any behavior performed through electronic or digital media by individuals or groups that repeatedly communicates hostile or aggressive messages to be harmed to inflict harm or discomfort on others (Randa, 2013)[9]. According to Li stated the practice of cyber-bullying is caused by one factor of anonymity, so that the perpetrators are able to harass or disturb the victim within 24 hours. Anonymity contained in each electronic communication model not only disguises identity but can reduce social accountability, making it easier for users to engage in hostility, aggressive action (Adiyanti, 2014) [10].

There are seven characteristics of cyber-bullying according to Slonje, Smith, and Frisen (Harahap, 2018: 29)[11], namely: 1) Influenced by the ability of individuals to master technology, 2) indirect interference, and the possibility of anonymity or unclear who is the culprit, 3) perpetrators usually do not see the victim's reaction at least in the short term, 4) bystander variation in cyber-bullying is more complex than bully behavior, 5) is different from bully behavior in which the perpetrator does so in order to get better status from the victim by showing aggressive treatment to the victim, 6 ) the possibility of more and more people becoming viewers, 7) it is very difficult to escape cyber-bullying because victims can access and send messages to their mobile phones or computers, or access comments on any website wherever they are.

Cyber-bullying which is done by using information and communication technology through social media can lead to various forms and types according to Willard (2007) [12] are: 1) flaming namely online fights using electronic messages with angry and vulgar language. Examples of cursing, gossiping, or mocking, 2) Harassment that is repeatedly sending messages that are offensive, abusive, and insulting on e-mails, short message service (SMS) or text messages on social networks, 3) Denigration is sending or posting cruel gossip or rumors about someone to damage the reputation or friendship, 4) Impersonation that is breaking into someone's account, posing as that person and sending messages to make that person look bad, make that person in trouble or danger, or damage the reputation or friendship of that person, 5) Outing is Sharing someone's confidential or embarrassing information online, 6) Tickery, Tricking someone into revealing confidential or embarrassing information, which is then shared online, 7) Exclusion, ex: deliberately excluding someone from an online group, such as a "friend list" or game, 8) Cyber-stalking, ex: Sending messages repeatedly that includes dangerous or very intimidating threats.

Impact of Cyber-bullying is the victim will experience a negative impact on social life, including life in the school environment. According to Jaffer \& Brazeau (2012) [13] explains the consequences arising from cyber-bullying in life at school, among others: (1) Having a bad attitude at school; (2) absent from school is often; (3) Difficulty to concentrating, remembering, and thinking; (4) Low achievement. Other impacts are more real, such as depression, low self-esteem, helplessness, social anxiety, suicidal ideation, fear, feeling weak and alone, low selfesteem, relationship estrangement, emotional problems and friendship problems (Cassidy et al., 2013)[14]

\section{III.CONCEPT OF MULTICULTURAL EDUCATION}

Multicultural education is an educational strategy utilizes the diversity of cultural backgrounds of students as one of the strengths to form multicultural attitudes. This is in line with the opinion of Faris \& Cooper (1994) [15], multicultural education is implemented as an effort to develop student competencies in viewing life from various cultural perspectives that are different from the culture they have, and to be positive towards cultural, racial, and ethnic differences. Thus educational institutions will be conditioned to reflect the practice of democratic values. This strategy is very useful, at least for schools as educational institutions can form a shared understanding of cultural concepts, cultural differences, balance, and democracy in a broad sense (Liliweri, 2009)[16].

Multicultural education according to Banks (1993)[17] consists of an idea, an education reform movement and an educational process. The concept combines the idea that all students include the characteristics of gender, social class, ethnicity, cultural sense are they must have equal opportunities to get an education at school. It is important to acknowledge the importance of cultural diversity in the form of lifestyle, social experience, personal identity, educational opportunities from within the community.

The goals of multicultural education can be identified: a). to function the role of schools in viewing the existence of diverse students; b). to assist students in establishing positive treatment for cultural, racial, ethnic, and religious differences; c). provide students with resilience by teaching them to make decisions and social skills; e).
Published By:

Blue Eyes Intelligence Engineering \& Sciences Publication (C) Copyright: All rights reserved. 
to assist students in building cross-cultural dependencies and to give them a positive picture of group differences (Skeel, 1995)[18]. To achieve the goals and objectives of multicultural education certainly requires quite a long time.

Banks (1993) [19] has described the evolution of multicultural education in four phases. First, there is an effort to unite ethnic studies in each curriculum. Second, this was followed by multiethnic education as an effort to implement educational equality through reforming the whole education system. Third, other marginal groups, such as women, disabled people, homosexuals and lesbians, began to demand fundamental changes in educational institutions.

The fourth phase of the development of theory, research and practice, attention to relations between races, sexes and class has produced a common goal for most theorists, if not practitioners, of multicultural education. The reform movement seeks to transform the educational process and educational institutions at all levels so that all students, regardless of race or ethnicity, disability, gender, social class and sexual orientation will enjoy equal opportunities to enjoy education.

\section{IV.RESEARCH METHODOLOGY}

According to researchers, this study had used a qualitative descriptive approach and the type of research had used is library research, collecting data or scientific papers aimed at research objects or data collection that is library (Sukmadinata, 2007) [20]. Or study carried out to solve a problem which is basically based on a critical and in-depth study of relevant library materials.

\section{V.DISCUSSION AND RESULTS}

\section{A. State high school 13 of Samarinda}

In the 2004/2005 academic year many students who became an athlete in the city of Samarinda experienced difficulties and took part in the lessons because they were treated the same as regular students, while they had to attend training centers / competitions and competitions at the regional, national and international levels. These activities reduce learning time at school, so that when the class rises experience problems and finally students do not move up the class. To address these problems Samarinda City Education Office established a school that can accommodate athletes in Samarinda City. The purpose of the school is to be achieved to create conducive learning, to realize unity and integrity, to realize faith and piety to God Almighty, to realize discipline and noble character, increase school and sports pretensions. These objectives are in line with the terms of reference for realizing multicultural education in schools.

\section{B. Implementation of Multicultural Education in Schools}

Factors that support the implementation of multicultural education in schools are the school climate, school's curriculum, school advice and infrastructure, the role of teachers, school programs and activities as well as students. The climate of the State high school 13 of Samarinda applies a culture of tolerance, has good manners and cultivates manners. Thus an environment that has awareness and is able to accept all differences, appreciate each other, respect, and act be tolerant of differences, with a sense of family that is owned by the school community.
In the multicultural school education curriculum integrated in all subjects such as Civic Education, Religion and Character, Mathematics, Sociology, Economics and so on as well as extracurricular activities in State high school 13 of Samarinda. The strategy used by schools for this implementation, schools and teachers design learning provides opportunities for all students (whether or not with special needs) regardless of gender, social class, ethnicity, race, religion, and culture in order to realize social justice, equal education and dedication in providing learning experiences so that students can achieve optimal development and achieve academic achievement in school. Schools have a responsibility to create a safe and comfortable learning environment for children or students (child friendly schools). The child or student has the right to feel safe and comfortable when in the school environment.

Infrastructure facilities owned by state high school 13 of Samarinda are enough filled the requirements set by the Education Office. Exist facilities are sufficient to be able to meet the various needs of students and to facilitate differences. For example schools provide space and religious teachers for each religion such as Islam, Christianity, Catholicism, Hinduism. In addition, the school also has traditional musical instruments for arts and culture education and various needs for sports with each of its supervisors.

The role of school teachers is to apply the exemplary system of honing, caring and fostering for the implementation of noble character education. So that, all teachers has an awareness of their role as role models and examples for students in schools in instilling and implementing the values of multicultural education. The teacher also carries out learning activities according to the needs of students, without discrimination. The teacher also shows respect and empathy for the child or student.

The school has a variety of self-development and extracurricular activities. The activity provides opportunities for students to develop and express themselves according to their needs, talents and interests, for all students without exception. Through this activity, it is also applied to the process of forming, planting and practicing the values of noble character which also supports the planting of multicultural values.

Students are still need to be increased about their inner awareness to appreciate the differences that are around them. Almost some students are able to mingle with other students without any problems with differences, both in terms of religion, ethnicity, culture and ability.

Schools have a responsibility to create a safe and comfortable learning environment for children or students (child friendly schools). The child or student has the right to feel safe and comfortable when in the school environment. At school, the teacher is also one of the factors that influence the growth of respect and empathy for children or students.

\section{The Method Applied at School}

State high school 13 of Samarinda has designs, plans and controls all stakeholders that can support the multicultural education process running well. Schools must design and design the learning process,
Published By:

Blue Eyes Intelligence Engineering \& Sciences Publication

(C) Copyright: All rights reserved.

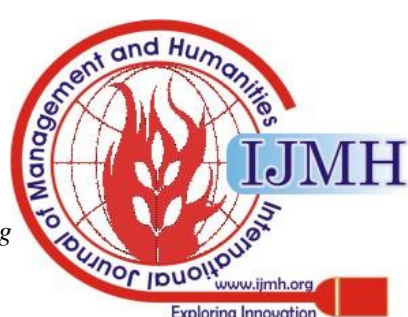


prepare curriculum and evaluation designs, and prepare teachers who have multicultural perceptions, attitudes and behaviors, so that they become a part that contributes positively to the development of multicultural attitudes of their students. In the process of designing learning in schools, especially in the teacher class, the learning process must reflect multicultural attitudes, it is hoped that students can be good citizens, be democratic, and respect human rights.

The method chosen is based on students' dynamics, relaxed and does not suppress students. When teaching in class the teacher also applies multicultural education by familiarizing the mutual respect for each other, creating a democratic classroom atmosphere, and instilling multicultural values routinely. In learning activities students can express opinions freely, all students are treated equally and nothing is discriminated against. The teacher teaches habits such as respecting opinions, respecting and respecting others without discrimination. The teacher sets an example and is an example to students.

In addition, to get around so as not to occur bullying and cyber-bullying behavior in schools to prevent through:

1. Provide students with an understanding of behavior categorized as cyber-bullying to students through classroom learning, student group discussions, drawings and nonviolent writing, and self-development and extracurricular activities

2. Give recognition that students can develop their knowledge, competencies in various ways so that they feel recognized and valued.

3. Making strict rules and commitments does not allow ridicule or exclusion of ethnic aspects and other aspects of students which sometimes continue on social media.

4. Students are taught not to feel more than their peers, for example, a screeching child 1 don't mock another friend who doesn't get a screech.

5. Utilizing technology and information in classroom learning to provide perspectives on ethical, cultural, religious differences and so on

6. Analysis of student seating plans, provide opportunities for children to be able to exchange seats in the classroom. When students do learning activities in the form of groups make sure the group is heterogeneous.

7. Teachers and school stakeholders are oversee the use of the internet by children without making children feel uncomfortable.

8. Teach children to be selective in choosing friends on social media and provide understanding not to post all activities on social media too often to avoid bad comets.

With these policies, it is expected that education will make a significant contribution to the problem of cyber-bullying. Through education in schools the development of open attitudes towards diversity, tolerance, and understanding togetherness as needs will be able to be invested and developed as capital in the life of the nation and state so that cyber-bullying events can be prevented before they occur.

\section{VI.CONCLUSION}

Cyber-bullying is one of the increasingly widespread problems, including among students at school. Open insight, wisdom, and creativity in schools are needed for handling it. The right perspective on school functions will greatly help children deal with and overcome the problems they experience. Cyber-bullying is any behavior performed through electronic or digital media by individuals or groups that repeatedly communicates hostile or aggressive messages intended to inflict harm or discomfort on others.

Various forms and types of Cyber-bullying such as flaming, Harassment, Denigration, Impersonation, Outing, Tickery, Exclusion and Cyber stalking The impact of Cyber-bullying is the victim will experience a negative impact in social life including the life in the school environment such Having a bad attitude at school, Often not attending school, Difficult to attend school concentration, remembering, and thinking; and low achievement. Other impacts are more obvious, such as depression, low self-esteem, helplessness, social anxiety, suicidal ideation, fear, feeling weak and alone, low selfesteem, relationship estrangement, emotional problems and friendship problems.

The majority of cyber-bullying events are caused by a) anger, hurt, revenge or frustration, b) thirst for power by accentuating the ego so that it hurts others, c) feeling bored and have the ability to do hacking, d) entertainment only in order to laugh or get a reaction , and e) accidental mass implantive and emotional comments.

Multicultural education is a renewal, process and form of education with the aim of providing opportunities for all children (both not and with special needs) without regard to negative gender, social class, ethnicity, race, religion, and culture as an embodiment of social justice, equal education and dedication in providing learning experiences so that students are able to achieve optimal development and achieve academically in school. Factors that support the implementation of multicultural education in schools are the school climate, school curriculum, school advice and infrastructure, the role of teachers, school programs and activities as well as students. The method chosen is based on students' dynamics, relaxed and does not suppress students. When teaching in class the teacher also applies multicultural education by familiarizing the mutual respect for each other, creating a democratic classroom atmosphere, and instilling multicultural values routinely.

With these policies, it is expected that education will make a significant contribution to the problem of cyber-bullying. Through education in schools the development of open attitudes towards diversity, tolerance, and understanding togetherness as needs will be able to be invested and developed as capital in the life of the nation and state so that cyber-bullying events can be prevented before they occur.

\section{REFERENCES}

1. Bauman S, Toomey R, Walker J. (2013). Associations among bullying, cyberbullying, and suicide in high school students. Journal of Adolescence, 36(2), 341-350.

2. Bauman, S. (2007). Cyberbullying: a Virtual Menace. National Coalition Against Bullying National Conference (pp. 1-23). Melbourne, Australia: University of Arizona Tucson.

3. APJII, Team. (2018). Potret Zaman Now Pengguna Dan Perilaku Internet Indonesia. Jakarta: APJII.

4. Anderson, J. Bresnahan, M. \& Musatics, C. (2014). Combating Weight-Based Cyberbullying on Facebook with the Dissenter Effect. Mary Ann Liebert, Inc. Publisher, 17(5), 281-286

5. Palladino, B., Nocentini A, Menesini E. (2015). Psychometric properties of the Florence CyberBullying-CyberVictimization Scales. Cyberpsychol Behav Soc , 18(2), 112-119. 
6. Anderson, M. (2018). A Majority of Teens Have Experienced Some Form of Cyberbullying. Washington DC: Pew Reseach Center.

7. Bauman S, Toomey R, Walker J. (2013). Associations among bullying, cyberbullying, and suicide in high school students. Journal of Adolescence, 36(2), 341-350.

8. Waasdorp, T., \& Bradshaw, C. (2015). The Overlap Between Cyberbullying and Traditional Bullying. Journal Of Adolescent Health, 56(5), 483-488.

9. Randa, R. (2013). The influence of the cyber-social environment on fearof victimization: Cyberbullying and school. Security Journal, 26(4), 331-348.

10. Mawardah, M., \& Adiyanti, MG. (2014). Regulasi Emosi dan Kelompok Teman Sebaya Pelaku Cyberbullying. Jurnal Psikologi, 41(1), 60-73.

11. Harahap, A.K (2018). Gambaran Tingkat Kecemasan Pada Remaja Korban Cyberbullying di Kota Medan. Psikologi. Medan: Universitas Sumatra Utara.

12. Willard, N. (2007). Cyberbullying and cyberthreats. Washington: U.S: Department of Education.

13. Jaffer, Mobina,S.B, \& Brazeau, P (2012). Cyberbullying Hurts:Respect for Rights in the Digital Age. Canada: Standing Senate Committee on Human Rights

14. Cassidy, W., Faucher, C., \& Jackson, M. (2013). Cyberbullying among youth: A comprehensive review of current international research and its implications and application to policy and practice. School Psychology International, 575-612.

15. Cooper, P. F. (1994). Elementary Social Studies: a Whole language Approach. Iowa: Brown\&Benchmark Publishers.

16. Liliweri, A. (2009). Prasangka dan Konflik ; Komunikasi Lintas Budaya Masyarakat Multikultur. Yogyakarta: LKiS.

17. Banks, J. A. (1993). Multicultural Education: Historical Development, Dimensions, and Practice. Review of Research in Education. American Educational Research Association, 19, 3-49.

18. Skeel, D. (1995). Elementary Social Studies: Challenge for Tomorrow's World. New York: Harcount Brce College Publishers.

19. Banks, J. A. (1993). Multicultural Education: Historical Development, Dimensions, and Practice. Review of Research in Education. American Educational Research Association, 19, 3-49.

20. Sukmadinata, N. S., Metodologi Penelitian Pendidikan, Bandung: Remaja Rosdakarya, 2007

\section{AUTHOR PROFILE}

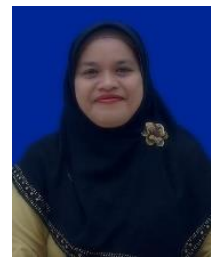

Sylvi Marini. sylvimarini.2017@student.uny.ac.id The Author is currently studying in postgraduate social studies education at Universitas Negeri Yogyakarta. The author is interested in research related to cyberbullying issues.

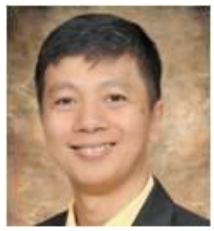

Setyabudi

Indartono,

Ph.D. setyabudi_indartono@uny.ac.id Scopus Author ID 37123968000, Assoc. Prof. in Human Resources Management, Dept. Head of Management School, Universitas Negeri Yogyakarta.

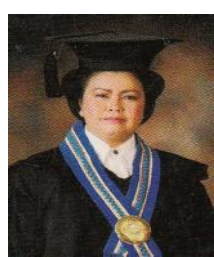

Prof. Dr. Farida Hanum, M.S faridahanum@uny.ac.id UNY Master's Program Lecturer,Yogyakarta State University, Yogyakarta, Indonesia

Blue Eyes Intelligence Engineering

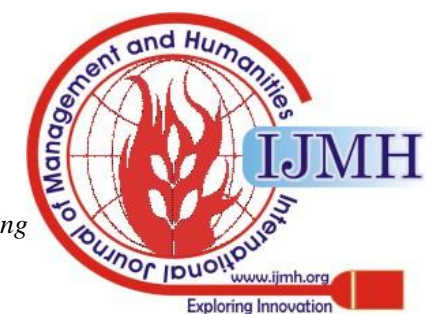

